\title{
Nutrient stimulation of bacterioplankton growth in Tuamotu atoll lagoons
}

\author{
J.-P. Torréton ${ }^{1, *}$, V. Talbot ${ }^{1}$, N. Garcia ${ }^{2}$ \\ ${ }^{1}$ Institut de Recherche pour le Développement, Laboratoire HEA, BP 5045, 34032 Montpellier cedex 1, France \\ ${ }^{2}$ CNRS, Laboratoìre d'Océanographie el de Biogéochimie UMR 6535 (COM-OSU), Campus de Luminy, \\ 13288 Marseille, France
}

\begin{abstract}
Knowledge of the factors regulating bacterioplankton growth is of considerable importance in attempts to understand the functioning of biogeochemical cycles and particularly their evolution after perturbation. We first tested the effect of nutrient additions on the growth of bacterioplankton assemblages collected from 10 atoll lagoons of various morphologies in the Tuamotu Archipelago and in oceanic surface waters surrounding them. Then, we examined these responses in relation to ambient nutrient concentrations and bacterioplankton community turnover rates in these lagoons. The lagoons studied exhibited a range of $\mathrm{NH}_{4}(\sim 0$ to $0.7 \mu \mathrm{M}), \mathrm{NO}_{2}+\mathrm{NO}_{3}(\sim 0$ to $0.5 \mu \mathrm{M})$, and $\mathrm{PO}_{4}(\sim 0$ to $0.3 \mu \mathrm{M}$ ) concentrations. Responses were assessed on bacterioplankton grown in seawater cultures during 2 seasons (end of rainy season, end of dry season) and amended with $\mathrm{NH}_{4}-\mathrm{N}, \mathrm{PO}_{4}-\mathrm{P}$ or glucose-C in all possible combinations. The 10 lagoons investigated exhibited various responses to nutrient additions. Including co-stimulations, bacterioplankton growth was stimulated by $\mathrm{C}, \mathrm{N}$ and $\mathrm{P}$ additions in 4 , 10 and 4 cases, respectively. One atoll lagoon showed inconsistent responses during both cruises. Another one showed no response to any nutrient addition. On the other hand, the oceanic subsurface samples showed a systematic stimulation by glucose, in one case with a concomitant positive effect of $\mathrm{N}$. Expressed as percentages of the unamended controls, responses to ammonium and phosphorus additions in the different lagoons investigated appeared to decrease with increasing ammonium and phosphorus concentrations, respectively. This correspondence suggests that in situ concentrations reflect the nutrient status of bacterioplankton in the sites visited. $\mathrm{NH}_{4}-\mathrm{N}$ appeared as the most frequently stimulatory nutrient in the atolls investigated. This is in agreement with the close $\log -\log$ correlation $\left(\mathrm{p}<0.001\right.$ ) observed between bacterioplankton turnover rates and $\mathrm{DIN} / \mathrm{PO}_{4}$ ratio.
\end{abstract}

KEY WORDS: Atoll lagoon · Bacterioplankton · Nutrient limitation · Ammonium - Phosphorus

\section{INTRODUCTION}

The classical view of heterotrophic bacterioplankton as nutrient remineralizers has been challenged by the examination of bacterioplankton-nutrient relationships, pointing to a significant uptake of dissolved inorganic nutrients by bacterioplankton (Kirchman 1994). Heterotrophic bacteria have been shown to compete successfully with phytoplankton for phosphate in chemostat experiments (Currie \& Kalff 1984), possibly due to their higher affinity for this nutrient (Cotner \& Wet-

\footnotetext{
- Present address: Institut de Recherche pour le Développement, Université Montpellier II, UMR 5556, Case 093, 34095 Montpellier cedex 05, France. E-mail: torreton@ird.fr
}

zel 1992). In culture experiments, Caron et al. (1988) showed that bacteria competed efficiently with phytoplankton for $\mathrm{NH}_{4}{ }^{+}$when substrates available for bacterial growth presented a high $\mathrm{C}: \mathrm{N}$ ratio. At Sapelo Island and in Gulf Stream waters, Wheeler \& Kirchman (1986) found that, on average, $78 \%$ of ${ }^{15} \mathrm{NH}_{4}{ }^{+}$uptake was due to prokaryotes, of which heterotrophic bacteria contributed significantly. Suttle et al. (1990) showed that up to $50 \%$ of ${ }^{13} \mathrm{NH}_{4}{ }^{+}$added was taken up by cells $<1 \mu \mathrm{m}$, and that this proportion decreased with increasing nutrient concentrations. Therefore, bacteria are likely to outcompete phytoplankton for $\mathrm{NH}_{4}{ }^{+}$, under low $\mathrm{NH}_{4}{ }^{+}$concentrations and relatively high $\mathrm{C}: \mathrm{N}$ ratios of available substrates. The occurrence of significant uptake of inorganic nutrients by natural communities of bacterioplankton suggests that they 
might be limited by inorganic nutrients in oligotrophic areas.

Among the 425 atolls scattered in the world's oceans, 84 are situated in French Polynesia and 77 belong to the Tuamotu-Gambier Archipelago. Situated in a large anticyclonic gyre, these atolls are surrounded by oligotrophic waters. Their lagoons are of great importance to the economy of French Polynesia, where pearl oyster Pinctada margaritifera farming represents the major source of export. Determining the factors controlling planktonic production is therefore of critical importance in this area. In coral reef environments, characterized by high calcium carbonate contents, phosphorus is believed to play a major role in the control of net production (Smith \& Atkinson 1984), and iron was also invoked as a potential limiting nutrient in these environments. High intracellular levels of flavodoxin were interpreted as an index of Fe limitation in the blue-green alga Phorbidium sp. at Davies Reef (Great Barrier Reef, Australia; Entsch et al. 1983) and iron was observed to limit the growth of Caribbean seagrasses growing over carbonate sediments (Duarte et al. 1995). Few data are available about nutrient control of pelagic production in atoll lagoons (Dufour \& Berland 1999, Sakka et al. 1999).

To date, bacterioplankton remains poorly studied in atoll lagoons and the response of atoll lagoon bacterioplankton to nutrient additions remains untested. Generation times for bacterioplanktonic assemblages determined using ${ }^{3} \mathrm{H}$-thymidine incorporation are generally long in atoll lagoons (Yoshinaga et al. 1991, Torréton \& Dufour 1996a,b). In addition, the carbon growth efficiency (CGE) determined in Tikehau and Takapoto lagoons (Tuamotu) (Torréton et al. 1997) is in the lower range of literature values (del Giorgio \& Cole 1998). It was established that CGE decreases with nutrient limitation (Kroer 1993). These observations argue for a bottom-up limitation of heterotrophic bacterioplankton in these atoll lagoons.

The assessment of bacterioplankton control by nutrient availability is not trivial, since no single method is able to unequivocally demonstrate nutrient limitation. Nutrient-enrichment bioassays represent the most direct method for assessing the nutrient status of phytoplankton or bacterioplankton populations. They have been widely used for this purpose although the enclosure of water samples is known to possibly change the hydrodynamics, the nutrient dynamics and the foodweb structure. Potential nutrient limitation of microbial communities determined from bioassays should therefore be contrasted with other indexes of nutrient limitation.

Atoll lagoons display a high geomorphological diversity with large variations in total lagoon area, emerged land, average depth, and exchange with the ocean
(Andréfouët 1998). This wide diversity involves variations in biomass (Delesalle \& Sournia 1992, Dufour \& Harmelin-Vivien 1997), nutrient levels (Dufour \& Harmelin-Vivien 1997) and, therefore, likely specific growth rates of planktonic assemblages among atolls. At, or near, steady-state, ambient nutrient concentrations should reflect the equilibrium between supply and demand. This variability provides the opportunity to test if the nutrient status of bacterioplankton, as assessed experimentally using bioassays, is consistent with ambient nutrient levels and the turnover rates of bacterioplankton.

The objective of this study was to investigate whether bacterioplankton are nutrient limited in 10 Tuamotu atoll lagoons of various morphologies. For this purpose, we (1) determined the responses of bacterioplankton communities to nutrient additions $(\mathrm{C}, \mathrm{N}$, $P)$ in batch cultures, and (2) examined these responses in relation to ambient nutrient concentrations and specific turnover rates of bacterioplankton in the same lagoons. These growth characteristics were investigated during 2 different seasons.

\section{MATERIAL AND METHODS}

Sampling. This study was part of a larger comparative study of atoll lagoons (Typatoll program) intending to determine how the geomorphological type of atolls influences their structure and functioning (Dufour \& Harmelin-Vivien 1997).

Samples were collected from 10 atoll lagoons located between $15^{\circ} 45^{\prime} \mathrm{S}$ to $18^{\circ} 03^{\prime} \mathrm{S}$ and $141^{\circ} 55^{\prime} \mathrm{W}$ to $145^{\circ} 09^{\prime}$ $\mathrm{W}$ in the Tuamotu Archipelago (Fig. 1). The main characteristics of these atolls are presented in Table 1.

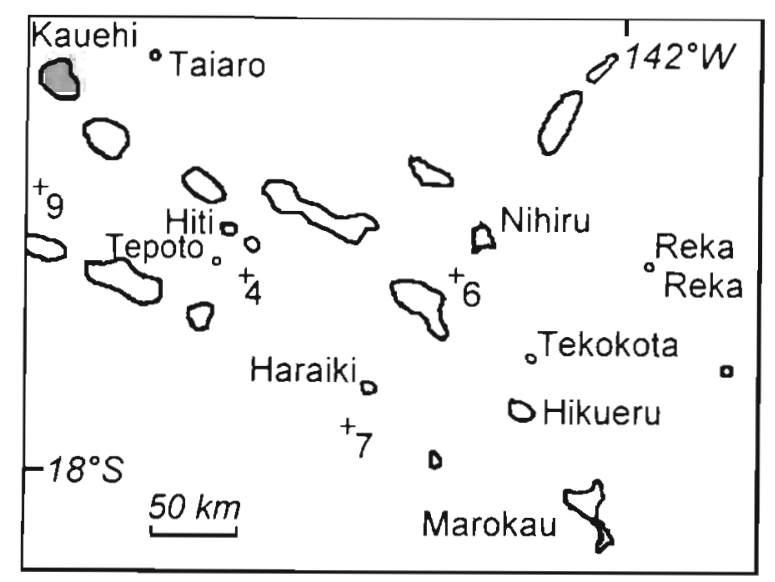

Fig. 1. Location of the 10 atolls and the 4 oceanic sites visited during Typatoll cruises. The atolls studied are in grey. + oceanic Stns $4,6,7$ and 9 
Table 1. Main characteristics of the 10 atolls studied in the Tuamoto Archipelago

\begin{tabular}{|c|c|c|c|c|c|c|c|}
\hline Atoll & $\begin{array}{l}\text { Latitude } \\
\qquad\left({ }^{\circ} \mathrm{S}\right)\end{array}$ & $\begin{array}{l}\text { Longitude } \\
\left({ }^{\circ} \mathrm{W}\right)\end{array}$ & $\begin{array}{c}\text { Total area } \\
\left(\mathrm{km}^{2}\right)\end{array}$ & $\begin{array}{l}\text { Lagoon area } \\
\qquad\left(\mathrm{km}^{2}\right)\end{array}$ & $\begin{array}{c}\text { Depth }^{a} \\
\text { (m) }\end{array}$ & Permeability $^{b}$ & No. of passes \\
\hline Haraiki & $17^{\circ} 28^{\prime}$ & $143^{\circ} 26^{\prime}$ & 24.6 & 10.4 & 12 & 18.9 & 1, large, deep \\
\hline Hikueru & $17^{\circ} 35^{\prime}$ & $142^{\circ} 38^{\prime}$ & 107 & 82 & 28 & 17.9 & 0 \\
\hline Hiti & $16^{\circ} 43^{\prime}$ & $144^{\circ} 06^{\prime}$ & 25.0 & 15 & 10 & 19.4 & 0 \\
\hline Kauehi & $15^{\circ} 52^{\prime}$ & $145^{\circ} 09^{\prime}$ & 343 & 315 & 45 & 21.6 & 1, large, deep \\
\hline Marokau & $18^{\circ} 03^{\prime}$ & $142^{\circ} 16^{\prime}$ & 256 & 217 & 28 & 17.4 & 1 , small, shallow \\
\hline Nihiru & $16^{\circ} 41^{\prime}$ & $142^{\circ} 50^{\prime}$ & 100 & 80 & 21 & 24.5 & 0 \\
\hline Reka-Reka & $16^{\circ} 50^{\prime}$ & $141^{\circ} 55^{\prime}$ & 5.2 & 0.7 & 1 & 1.7 & 0 \\
\hline Taiaro & $15^{\circ} 45^{\prime}$ & $144^{\circ} 38^{\prime}$ & 17 & 12 & 13 & 0.9 & 0 \\
\hline Tekokota & $17^{\circ} 19^{\prime}$ & $142^{\circ} 34^{\prime}$ & 7.3 & 5.1 & 3 & 59.5 & , very large, shallow \\
\hline Tepoto Sud & $16^{\circ} 49^{\prime}$ & $144^{\circ} 17^{\prime}$ & 6.2 & 1.6 & 5 & 15.2 & 1, small, shallow \\
\hline
\end{tabular}

These sites were visited twice, in November 1995 (Typatoll 3 [TYP3] cruise, end of dry season) and in March 1996 (TYP4 cruise, end of rainy season). The response of bacterioplankton to nutrient additions was assessed at the central station of every lagoon. Previous work has shown that within-lagoon variations are low for bacterioplankton in 2 Tuamotu atoll lagoons (Torréton \& Dufour 1996a,b). These low intra-lagoonal variations were verified for most variables during the Typatoll cruises (Dufour \& Harmelin-Vivien 1997). These central stations were therefore considered representative of average lagoon conditions.

Additional samples were collected from 6 oceanic stations (between $15^{\circ} 47^{\prime} \mathrm{S}$ to $17^{\circ} 30^{\prime} \mathrm{S}$ and $141^{\circ} 57^{\prime} \mathrm{W}$ to $145^{\circ} 37^{\prime} \mathrm{W}$ ) during each cruise (Stns 1 to 6 during TYP3, Stns 7 to 12 during TYP4). Samples from only 2 stations during each cruise were assayed for bacterioplankton response to nutrient additions during each cruise (Stns 4,6,7 and 9, see locations in Fig. 1).

Subsurface (at $0.5 \mathrm{~m}$ depth) water samples were collected in the morning directly in acid-washed polyethylene bottles and were kept in the dark at in situ temperature until processed on board within $2 \mathrm{~h}$.

Batch experiments. Water was gravity filtered through $0.6 \mu \mathrm{m}$ Nuclepore membranes $(47 \mathrm{~mm})$ to remove bacterivores and pico-autotrophs in 3 parallel filtration manifolds. The first $200 \mathrm{ml}$ of each filtrate was discarded. The 3 filtrates were pooled, and $150 \mathrm{ml}$ was then distributed in each of 8 sterile polystyrene flasks (capacity $200 \mathrm{ml}$ ) previously rinsed with the $0.6 \mu \mathrm{m}$ filtrate. The 8 flasks were then immediately amended with ultrapure nutrients (Merck Suprapur $\left.{ }^{(}\right) . \mathrm{NH}_{4}-\mathrm{N}$ $\left(\mathrm{NH}_{4} \mathrm{Cl}, 3.3 \mu \mathrm{M}\right.$ final concentration), $\mathrm{PO}_{4}-\mathrm{P}\left(\mathrm{Na}_{2} \mathrm{HPO}_{4}\right.$, $0.67 \mu \mathrm{M}$ final concentration) and glucose $(5 \mu \mathrm{M}$ final concentration, $30 \mu \mathrm{M}$ glucose-C) were added following a $2^{3}$ factorial design. The amended flasks were then incubated in the dark at ambient temperature (28 to $30^{\circ} \mathrm{C}$ ) in an insulated box. Growth responses of bacte- rioplankton in the batch cultures were estimated from thymidine (TdR) incorporation rates determined approximately every $12 \mathrm{~h}$ for $48 \mathrm{~h}$. TdR incorporation rates, showed generally minor differences between treatments during the first $12 \mathrm{~h}$. Differences between treatments were consistent 24,36 and $48 \mathrm{~h}$ after inoculation. The results were expressed as the cumulated production (production in pmol TdR $\mathrm{I}^{-1}$ integrated over the entire culture duration) relative to that in control flasks (unamended).

No replicate enrichment was made during TYP3 and TYP4 cruises. In one further experiment in April 1997. at Takapoto (Tuamotu), the amendments were made in duplicates to evaluate the reproducibility of the experimentation. Bacterioplankton growth within duplicate nutrient additions differed, on average, by $12 \%$ of the mean ( $\mathrm{n}=8$, range: 5 to $23 \%$ ).

The consistency of responses between treatments was tested by assuming that response to combinations of added nutrients (e.g. $\mathrm{C}+\mathrm{N}, \mathrm{C}+\mathrm{P}$ ) was the sum of the responses to individual elements ( $C, N$ and $P$ ). This hypothesis leads to a set of 8 equations with 3 unknown variables (responses to $\mathrm{C}, \mathrm{N}$ and $\mathrm{P}: R_{\mathrm{C}}, R_{\mathrm{N}}, R_{\mathrm{P}}$ ). For example, response to $\mathrm{C}+\mathrm{N}$ addition $\left(R_{\mathrm{CN}}\right)$ equals $1 \times R_{\mathrm{C}}+$ $1 \times R_{\mathrm{N}}+0 \times R_{\mathrm{p}}$. Multiple regression was used to estimate $R_{\mathrm{C}}, R_{\mathrm{N}}$ and $R_{\mathrm{P}}$ (Statistica ${ }^{\otimes}$ software). The validity of this assumption was established by the significance of the regression. In some cases, responses were unclear and the results were re-analyzed after eliminating the most prominent outliers.

Bacterial abundance and growth. Bacterial abundance was determined on $0.5 \mathrm{~m}$ deep water samples at 5 different stations in each atoll lagoon using epifluorescence microscopy after DAPI staining (Porter \& Feig 1980). Bacterioplankton growth, was estimated on the same samples from each atoll lagoon and in the batch cultures using the same protocol. Ten ml duplicates of each subsample were incubated in the dark at $28^{\circ} \mathrm{C}$ 
with ${ }^{3} \mathrm{H}-[$ methyl] thymidine (20 nM final concentration, $1.70 \mathrm{TBq} \mathrm{mol}{ }^{-1}$, Amersham TRK 637) for $30 \mathrm{~min}$. Incubation was terminated with buffered formaldehyde and unlabeled thymidine $(2 \%$ and $1 \mathrm{mM}$ final concentrations, respectively). Controls were run by adding formaldehyde and unlabeled thymidine before ${ }^{3} \mathrm{H}$ [methyl]thymidine.

Samples were then collected on Nuclepore membranes $(0.2 \mu \mathrm{m}$ pore-size) and rinsed with $0.2 \mu \mathrm{m}$ filtered lagoon water using a gentle vacuum $\left(<10^{4} \mathrm{~Pa}\right)$. The vacuum was disconnected and the filters, still mounted in the filtration apparatus, received $15 \mathrm{ml}$ of $5 \%$ trichloro-acetic acid (TCA). After $15 \mathrm{~min}$ the vacuum was reapplied and the filters were rinsed 4 times with $5 \mathrm{ml}$ of ice-cold $5 \%$ TCA and once with $3 \mathrm{ml}$ of ice-cold ethanoi ( $80 \%$ in water). The filters were then stored in scintillation vials at $-20^{\circ} \mathrm{C}$ until processed at the laboratory, within $3 \mathrm{wk}$. Labeled DNA in the vials was hydrolysed for $30 \mathrm{~min}$ with $0.5 \mathrm{ml} 0.5 \mathrm{~N} \mathrm{HCl}$ at $100^{\circ} \mathrm{C}$. After cooling, the vials received $10 \mathrm{ml}$ of scintillation cocktail before radioactivity determinations. Radioactivity was determined after quench correction with external standards and bacterial production was computed from $\mathrm{TdR}$ incorporation by subtracting control values, assuming labeled DNA to represent $73.6 \%$ of the label in the TCA precipitate (Torréton \& Dufour 1996a) and using $0.99 \times 10^{18}$ cells produced per mol TdR incorporated in DNA (Torréton \& Dufour 1996b).

Nutrient concentrations. Dissolved organic carbon (DOC), nitrogen (DON) and phosphorus (DOP), $\mathrm{NH}_{4}{ }^{+}$, $\mathrm{NO}_{2}+\mathrm{NO}_{3}$ and $\mathrm{PO}_{4}$ concentrations were estimated systematically on in situ samples. $\mathrm{NH}_{4}{ }^{+}, \mathrm{NO}_{2}+\mathrm{NO}_{3}$ and $\mathrm{PO}_{4}$ were determined at the end $(48 \mathrm{~h})$ of the culture period. Analyses for $\mathrm{PO}_{4}$ and $\mathrm{NH}_{4}{ }^{+}$were made on board on unfiltered samples according to the procedures of Murphy \& Riley (1962) and Koroleff (1970). For the $\mathrm{NO}_{2}+\mathrm{NO}_{3}$ determination, $20 \mathrm{ml}$ of seawater were collected in a polyethylene flask; $100 \mu \mathrm{l}$ of $\mathrm{HgCl}_{2}$ were added to preserve the sample. $\mathrm{NO}_{2}+\mathrm{NO}_{3}$ were analyzed on unfiltered samples 1 mo after the cruise following the classical methods of Wood et al. (1967) on a Technicon autoanalyzer. DON and DOP concentrations were determined in $40 \mathrm{ml}$ samples of seawater, filtered onto Whatman GF/F membranes previously combusted at $450^{\circ} \mathrm{C}$ for $24 \mathrm{~h}$, and stored in $50 \mathrm{ml}$ Pyrex bottles (Duran Schott). Before the cruise, the bottles underwent a preliminary digestion (without sample) in order to completely remove any trace of organic matter. $200 \mu \mathrm{l}$ of $\mathrm{HgCl}_{2}$ were added to the samples to stop all biological activity. Analyses were performed $1 \mathrm{mo}$ later in the laboratory according to the wet-oxidation procedure method (Pujo Pay \& Raimbault 1994). $\mathrm{NO}_{3}$ and $\mathrm{PO}_{4}$ obtained were measured on a Technicon autoanalyzer using, respectively, the methods of Wood et al. (1967) and Murphy \& Riley (1962). DON and DOP concentrations were obtained by removing the dissolved inorganic nitrogen (DIN) and phosphorus (DIP) concentrations measured on the same sample and eventually the particulate fraction if the sample was unfiltered.

Samples for DOC determinations were preserved with $\mathrm{HgCl}_{2}\left(10 \mathrm{mg} \mathrm{l}^{-1}\right)$ and $\mathrm{HCl}(0.03 \mathrm{~N})$ in Teflon capped glass tubes. DOC concentration was estimated from standard HTCO technique using a Shimadzu TOC 5000 analyzer. Samples were not filtered but were corrected for POC content determined in parallel samples with a Leco CHN analyzer (details in Pagès et al. 1997).

\section{RESULTS \\ Nutrients, bacterioplankton biomass and productivity}

The 10 lagoons studied showed an important range of nutrient concentrations (Table 2). Average subsurface $\mathrm{NH}_{4}{ }^{+}$concentrations ranged from $0.01 \mu \mathrm{M}$ at Nihiru (TYP3), Taiaro (TYP4), and Tepoto Sud (TYP4) to $0.72 \mu \mathrm{M}$ at Reka-Reka (TYP4). $\mathrm{NO}_{2}+\mathrm{NO}_{3}$ concentrations ranged from undetectable levels at Hikueru, Kauehi and Taiaro (TYP3) to $0.48 \mu \mathrm{M}$ at Tepoto Sud (TYP3). $\mathrm{PO}_{4}$ concentrations ranged from undetectable levels at Reka-Reka (TYP3) to $0.30 \mu \mathrm{M}$ at Tekokota (TYP4). Ammonium and nitrate concentrations were near detection limits at oceanic subsurface stations, while phosphate concentrations ranged from 0.17 to $0.24 \mu \mathrm{M}$ at TYP4 and TYP3 cruises, respectively,

Bacterioplankton characteristics also showed important variations among the sites visited. Bacterial abundance ranged from $0.22 \times 10^{6}$ cells $\mathrm{ml}^{-1}$ at Tekokota (TYP4) to $2.41 \times 10^{6}$ cells $\mathrm{ml}^{-1}$ at Hiti (TYP3). Bacterial productivity estimated from $\mathrm{TdR}$ incorporation ranged from $1.8 \times 10^{6}$ cells l-1 $\mathrm{h}^{-1}$ at Tekokota (TYP3) to $96 \times 10^{6}$ cells $\mathrm{l}^{-1} \mathrm{~h}^{-1}$ at Reka-Reka (TYP4). Bacterioplankton community turnover rates ranged from $0.07 \mathrm{~d}^{-1}$ at Kauehi and Marokau (TYP3) to $1.3 \mathrm{~d}^{-1}$ at Reka-Reka (TYP3). Average bacterioplankton characteristics at the 6 oceanic subsurface stations were very similar during the 2 cruises with $0.55 \times 10^{6}$ cells ml $^{-1}, 0.74 \times 10^{6}$ cells $\mathrm{l}^{-1} \mathrm{~h}^{-1}$ and $0.033 \mathrm{~d}^{-1}$, on average, for bacterial abundance, productivity and turnover rate, respectively.

\section{Batch culture experiments}

The magnitude of bacterioplankton responses to nutrient additions differed greatly among atoll lagoons 
and, sometimes, between the 2 cruises at the same sites (Table 3 ). Generally, the responses to substrate additions were consistent when nutrients were added alone or in combination. For example the bacterioplankton at Haraiki lagoon (TYP3) appeared to be stimulated by $\mathrm{N}$ as additions of $\mathrm{N}, \mathrm{C}+\mathrm{N}$, $\mathrm{N}+\mathrm{P}$ and $\mathrm{C}+\mathrm{N}+\mathrm{P}$ led to significant increases of $\mathrm{TdR}$ incorporation (Table 3). Indeed, the additive response to nutrient amendments were generally verified by multiple regression (Fig. 2, Table 4).

The lagoons presented a diversity of average additive responses to the treatments (Table 4). Stimulation by ammonium addition alone was observed in Haraiki (TYP3 and TYP4), Nihiru (TYP3 and TYP4), Taiaro (TYP3) and Kauehi (TYP4). A positive effect of phosphate amendment alone was observed in Reka-Reka (TYP3 and TYP4). Stimulation by glucose addition alone was observed in Hiti (TYP3 and TYP4), Tepoto (TYP3), in the 2 samples of ocean surface during TYP3 cruise and at oceanic Stn 7 (TYP4). Co-stimulation by $\mathrm{N}$ and $\mathrm{C}$ was observed in Tepoto Sud (TYP4) and oceanic Stn 3 (TYP4), where the greatest growths were observed following $\mathrm{C}+\mathrm{N}$ and $\mathrm{C}+\mathrm{N}+\mathrm{P}$ additions. Co-stimulation by $\mathrm{N}$ and $P$ was observed in Hikueru (TYP3 and TYP4). Taiaro samples during TYP4 cruise were greatly stimulated only following $\mathrm{C}+\mathrm{N}+\mathrm{P}$ addition $(226 \%$ increase compared to the control). Tekokota showed virtually no stimulation following any nutrient addition, except an indication of growth increase following $\mathrm{C}+\mathrm{N}+\mathrm{P}$ addition during the TYP3 cruise (Table 3 ).

In most of the sites, the magnitude of response of bacterioplankton growth to nutrient addition was not significantly different (Student's $t$-test) between the cruises made at the end of the rainy season and at the end of the dry season (Table 4).

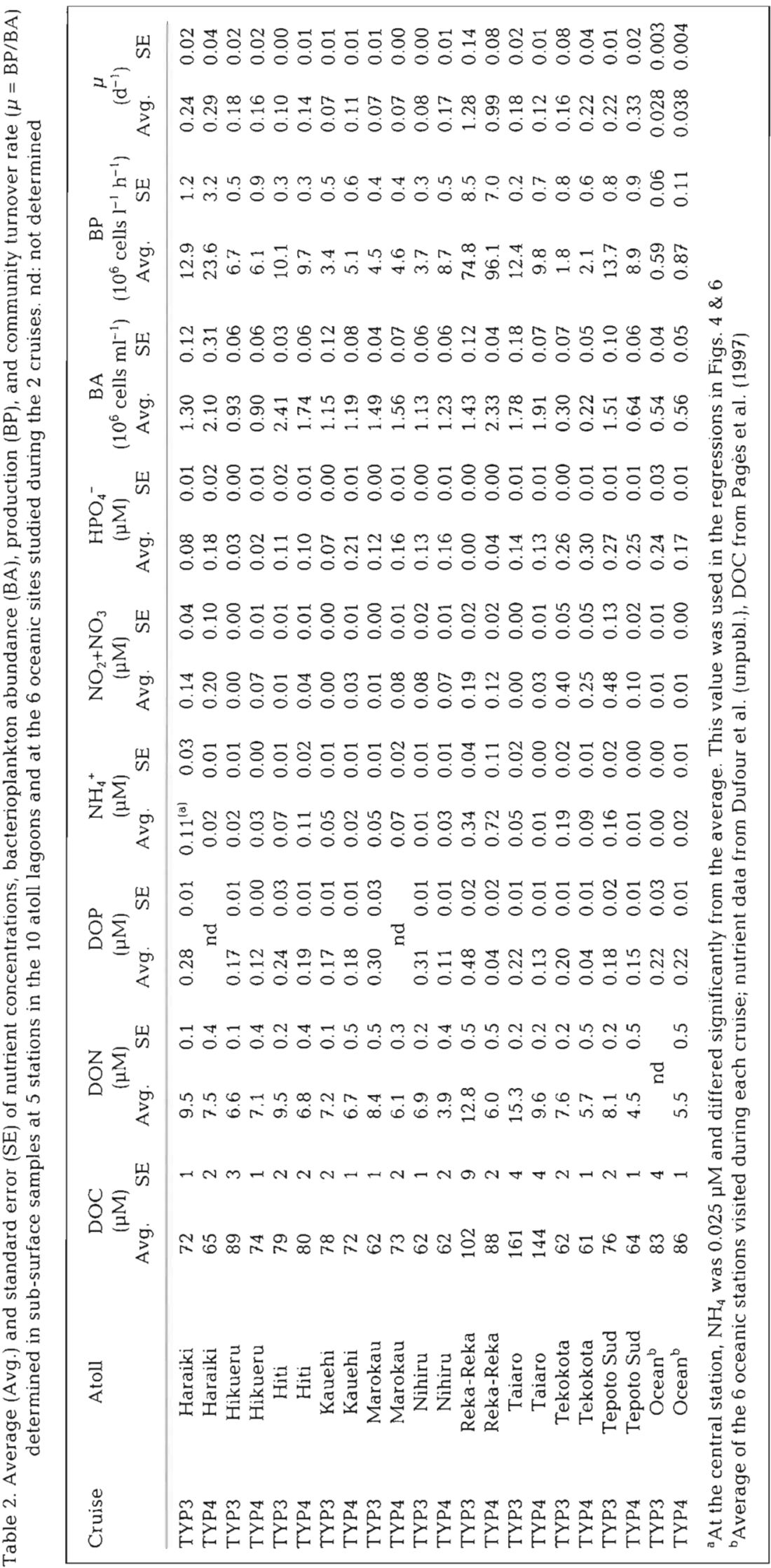


Table 3. Percent increase in cumulated $T d R$ incorporation relative to the unamended control

\begin{tabular}{|c|c|c|c|c|c|c|c|c|c|c|c|c|c|c|}
\hline \multirow[t]{2}{*}{ Site } & \multicolumn{7}{|c|}{ Typatoll 3 cruise (November 1995) } & \multicolumn{7}{|c|}{ Typatoll 4 cruise (March 1996) } \\
\hline & C & $\mathrm{N}$ & $\mathrm{P}$ & $\mathrm{C}+\mathrm{N}$ & $\mathrm{C}+\mathrm{P}$ & $N+P$ & $\mathrm{C}+\mathrm{N}+\mathrm{P}$ & $\mathrm{C}$ & $\mathrm{N}$ & $\mathrm{P}$ & $\mathrm{C}+\mathrm{N}$ & $C+P$ & $\mathrm{~N}+\mathrm{P}$ & $\mathrm{C}+\mathrm{N}+\mathrm{P}$ \\
\hline Haraiki & 22 & 77 & 38 & 99 & -8 & 95 & 154 & 19 & 82 & 30 & 75 & 21 & 84 & 115 \\
\hline Hikueru & 5 & 24 & 36 & 42 & 12 & 17 & 77 & 8 & 26 & 55 & 36 & 55 & 61 & 191 \\
\hline Hiti & 8 & -12 & 3 & 43 & 22 & -21 & 20 & 59 & 8 & 5 & 72 & 78 & 5 & 132 \\
\hline Kauehi & 28 & 108 & 169 & 22 & 45 & 46 & 361 & 55 & 83 & -3 & 81 & 43 & 101 & 59 \\
\hline Marokau & 81 & 39 & 8 & 15 & 9 & 48 & 35 & -7 & 67 & 4 & -9 & 11 & 33 & -9 \\
\hline Nihiru & 25 & 39 & 7 & 39 & 3 & 47 & 48 & 3 & 50 & 12 & 77 & 5 & 76 & 94 \\
\hline Reka-Reka & -3 & 9 & 41 & -4 & 64 & 88 & 102 & 1 & 4 & 36 & 6 & 31 & 35 & 73 \\
\hline Taiaro & -2 & 82 & 14 & 107 & 23 & 71 & 124 & 22 & 13 & 8 & 22 & 16 & -11 & 226 \\
\hline Tekokota & -11 & -11 & -11 & 24 & -11 & 6 & 71 & 23 & 0 & -7 & -11 & 4 & 1 & 18 \\
\hline Tepoto Sud & 243 & -1 & -7 & 43 & 21 & 11 & 68 & 100 & 116 & 16 & 285 & 39 & 95 & 365 \\
\hline Ocean $^{a}$ & 282 & 18 & -4 & 200 & 172 & -2 & 179 & 51 & 8 & 24 & 60 & 67 & 33 & 128 \\
\hline Ocean $^{b}$ & 38 & -13 & 7 & 86 & 100 & -5 & 61 & 76 & 54 & -9 & 99 & 74 & 53 & 124 \\
\hline
\end{tabular}

\section{Nutrient depletion in the batch cultures}

$\mathrm{NH}_{4}$ or $\mathrm{PO}_{4}$ depletion was estimated from the difference between $\mathrm{NH}_{4}$ or $\mathrm{PO}_{4}$ available at the beginning of the cultures (sum of in situ concentration and nutrient concentration added) and that estimated at the end of the incubations. Although large differences were observed among sites, average nutrient depletion at the end of the culture was generally in agreement with the response of bacterioplankton growth to nutrient addition. $\mathrm{NH}_{4}$ depletion in nitrogen-stimulated samples was significantly greater (Student's $t$-test) than in other lagoons following $\mathrm{N}, \mathrm{C}+\mathrm{N}$ and $\mathrm{N}+\mathrm{P}$ amendments (Fig. 3). The difference was not significant among lagoons following $\mathrm{C}+\mathrm{N}+\mathrm{P}$ amendments; this was likely because virtually all $\mathrm{NH}_{4}-\mathrm{N}$ available was removed from the batches at the end of incubations $(3.22 \pm 0.08$ and $3.09 \pm 0.09 \mu \mathrm{M}$, Fig. 3).

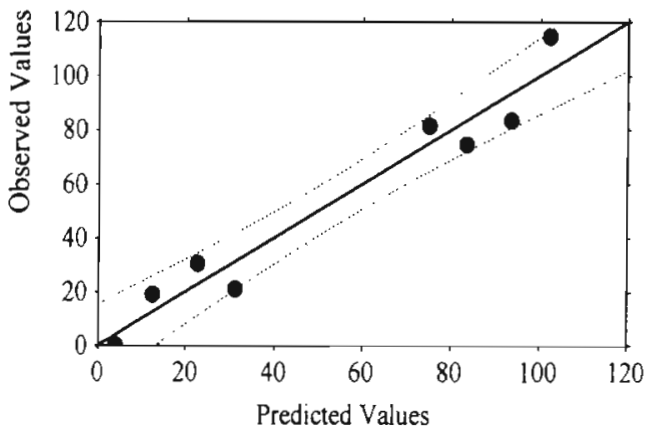

Fig. 2. Observed versus predicted responses of bacterioplankton from Haraiki atoll following nutrient additions during Typatoll 4 cruise. Responses are expressed as percent increase following nutrient addition relative to the control. Predicted responses $(R)$ are calculated from multiple regression: $R=$ intercept $+R_{\mathrm{C}} \mathrm{C}+R_{\mathrm{N}} \mathrm{N}+R_{\mathrm{P}} \mathrm{P}$, where $\mathrm{C}, \mathrm{N}$ and $\mathrm{P}$ take the value of 1 or 0 depending on whether the experiment involved a $\mathrm{C}, \mathrm{N}$ or $\mathrm{P}$ addition or not
In a similar way, average $\mathrm{PO}_{4}$ depletion was significantly greater in atolls not $\mathrm{N}$ limited following $\mathrm{C}$ and $\mathrm{C}+\mathrm{N}$ amendments and in the control batches. Other batches (except those following $\mathrm{N}+\mathrm{P}$ amendment) showed average differences in the expected way, although this difference was not significant (Fig. 3). $\mathrm{PO}_{4}-\mathrm{P}$ consumed represented only about $50 \%$ at greatest $(0.25 \pm 0.05$ and $0.30 \pm 0.04 \mu \mathrm{M}$ in the $\mathrm{C}+\mathrm{N}+\mathrm{P}$ batches) of the amount available at the beginning of the experiments.
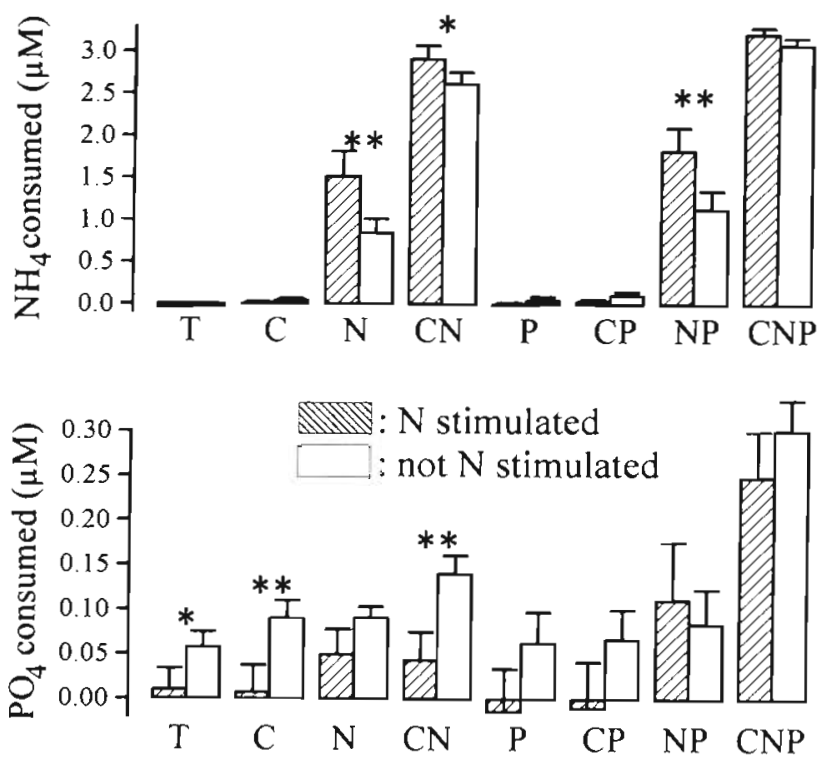

Fig. 3. $\mathrm{NH}_{4}$ and $\mathrm{PO}_{4}$ consumed $(\mu \mathrm{M})$ during the culture period in $\mathrm{N}$-limited (11 sites) and not $\mathrm{N}$-limited (13 sites) samples. Error bars represent SE. " $p<0.10 ; " p<0.05$; otherwise not significant. T: control 
Table 4 . Regression equations indicating the average additive response $(R)$ of bacterial production to $\mathrm{C}, \mathrm{N}, \mathrm{P}\left(R_{\mathrm{C}}, R_{\mathrm{N}}, R_{\mathrm{P}}\right)$ additions. Values represent the percent stimulation relative to control values determined from multiple regression: $R=$ intercept + $R_{\mathrm{C}} \mathrm{C}+R_{\mathrm{N}} \mathrm{N}+R_{\mathrm{P}} \mathrm{P}$, where $\mathrm{C}, \mathrm{N}$ and $\mathrm{P}$ take the value of 1 or $\mathrm{O}$ depending on whether the experiment involved a $\mathrm{C}, \mathrm{N}$ or $\mathrm{P}$ addition or not. Only significant effects are considered in the regression equations (ns: not significant) (see text). ${ }^{*} p<0.05,{ }^{*} p<0.01$, $\cdots p<0.001$. Effects not significantly different between the 2 seasons are underlined

\begin{tabular}{|c|c|c|c|c|c|c|c|c|c|c|c|c|}
\hline \multirow[t]{2}{*}{ Site } & \multicolumn{6}{|c|}{ Typato.l 3 (November 1995) } & \multicolumn{6}{|c|}{ Typatoll 4 (March 1996) } \\
\hline & $R_{\mathrm{C}}$ & $R_{\mathrm{N}}$ & $R_{\mathrm{p}}$ & Intercept & F-ratio & $R_{2}$ & $R_{C}$ & $R_{\mathrm{N}}$ & $R_{\mathrm{p}}$ & Intercept & $F$-ratio & $R_{2}$ \\
\hline Haraiki & & $\underline{93}{ }^{\circ}$ & & 13 & $22.6^{*}$ & 0.76 & & $71^{\cdots}$ & & 18 & $42.0^{\cdots}$ & 0.85 \\
\hline Hikueru & & $\underline{34}^{.}$ & $\underline{39} \underline{\circ}^{\circ}$ & 1 & $25.9^{\circ} \mathrm{c}$ & 0.91 & & $\underline{18}^{\circ}$ & $43^{*}$ & 8 & $25.1 \cdots d$ & 0.89 \\
\hline Hiti & $31^{\circ}$ & & & -7 & $11.4^{\circ}$ & 0.60 & $81^{\prime} \cdot$ & & & 4 & $25.7^{\cdots}$ & 0.78 \\
\hline Kauehi & & $\underline{84}^{\circ}$ & & 24 & $7.0^{\circ d}$ & 0.50 & & $\underline{57^{\circ}}$ & & 24 & $11.1^{\circ}$ & 0.59 \\
\hline Marokau & & & & & ns & & & & & & ns & \\
\hline Nihiru & & $34^{\circ}$ & & 9 & $31.1^{\circ}$ & 0.81 & & $69 \cdots$ & & 5 & $55.5^{\cdots}$ & 0.87 \\
\hline Reka-Reka & & & $\underline{73} \cdot$ & 1 & $27.4^{\circ}=$ & 0.79 & & & $\underline{41}^{\cdots}$ & 3 & $16.8 \cdots$ & 0.69 \\
\hline Taiaro & & $88^{*}$ & & 8 & $42.7^{\cdots} \cdots$ & 0.86 & & & & & ns & \\
\hline Tekokota & & & & & ns & & & & & & $\mathrm{ns}$ & \\
\hline Tepoto Sud & $\underline{43^{*}}$ & & & 1 & $12.2^{* e}$ & 0.65 & $141^{\prime}$ & $176^{\circ}$ & & -32 & $14.2^{\circ}$ & 0.79 \\
\hline Ocean $^{a}$ & $205^{\cdots}$ & & & 3 & $63.6^{\cdots}$ & 0.90 & $60^{*}$ & & & 16 & $10.1^{\bullet}$ & 0.56 \\
\hline Ocean $^{b}$ & $\underline{74}^{*}$ & & & -3 & $26.2^{\bullet}$ & 0.78 & $69 \cdots$ & $48^{\cdots} \cdots$ & & 1 & $61.8 \cdots$ & 0.95 \\
\hline $\begin{array}{l}{ }^{a} \text { Oceanic Str } \\
{ }^{b} \text { Oceanic Str } \\
{ }^{c} \text { Without C }+\end{array}$ & $\begin{array}{l}\text { is } 4 \text { (TYP } \\
\text { is } 6 \text { (TYP } \\
P \text { and } N\end{array}$ & $\begin{array}{l}\text { and } 7 \\
\text { and } 9\end{array}$ & $\begin{array}{l}\left.Y P_{4}\right) \\
\text { YP4) }\end{array}$ & $\begin{array}{l}{ }^{d} \text { Withou } \\
\text { eWithou }\end{array}$ & $\begin{array}{l}\mathrm{C}+\mathrm{N}+\mathrm{P} \\
\text { it } \mathrm{C}\end{array}$ & & & & & & & \\
\hline
\end{tabular}

\section{Responses to nutrient additions and ambient nutrient concentrations}

Most lagoon bacterioplankton assemblages responded primarily to nitrogen addition, although with varying intensity. At 2 sites (Reka-Reka and to a lesser degree Hikueru), P enrichment led to a greater stimulation than with $\mathrm{N}$ additions. The responses to ammonium additions tended to decrease, although not significantly $(\mathrm{p}=0.08)$, with increasing ammonium concentrations (Fig. 4). The oceanic samples did not fit into this pattern. Responses to $\mathrm{PO}_{4}$ additions also showed consistent trends with $\mathrm{PO}_{4}$ concentration in situ after exclusion of the oceanic samples (Fig. 5).

\section{Relationships between bacterioplankton turnover rates and ambient nutrient concentrations}

Another argument about possible nutrient limitation of bacterioplankton assemblages may be obtained from the correlations between in situ turnover rates of bacterioplankton and ambient nutrient concentrations. We therefore examined these correlations. The results obtained (Table 5) show the turnover rate of bacterioplankton to be significantly $(r=0.53, p=0.02)$ correlated to $\mathrm{NH}_{4}$ concentrations in the sites investigated during the TYP3 and TYP4 cruises. An even closer correlation was observed between turnover rate and $\mathrm{NH}_{4} / \mathrm{PO}_{4}$ ratio or DIN/PO ${ }_{4}$ ratio (Fig. 6). Turnover rates also appear to be highly significantly related to chlorophyll concentration and primary production (respectively $\mathrm{p}=0.003$ and $\mathrm{p}<$
0.011 , see Table 5); therefore we tested for the partial correlations with DIN/PO 4 . They were still significant after accounting for the correlation of bacterioplankton turnover rates with chl a or primary production $(r=0.65$ $p<0.01$ and $r=0.71, p<0.001$, respectively). There was no significant correlation between bacterioplankton

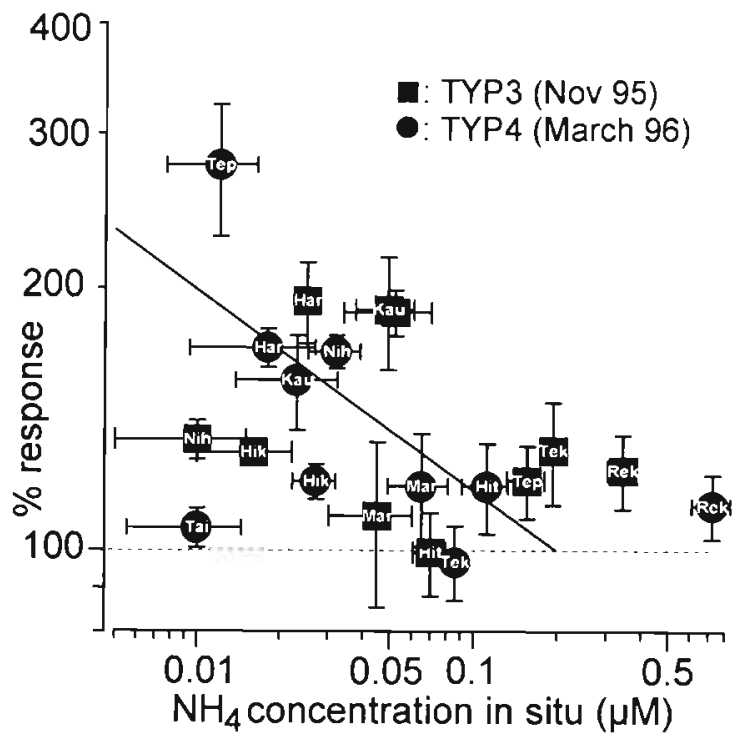

Fig. 4. Response to ammonium addition and ammonium concentration at the sites investigated. Dashed line at $100 \%$ represents control values. Har: Haraiki, Hik: Hikueru, Hit: Hiti Kau: Kauehi, Mar: Marokau, Nih: Nihiru, Rek: Reka-Reka, Tai: Taiaro, Tek: Tekakota, Tep: Tepoto. TYP3 and TYP4: Typatoll cruises. Error bars represent SE. Regression fit (log$\log$, model II) is not significant $(r=0.40, p=0.08)$ 


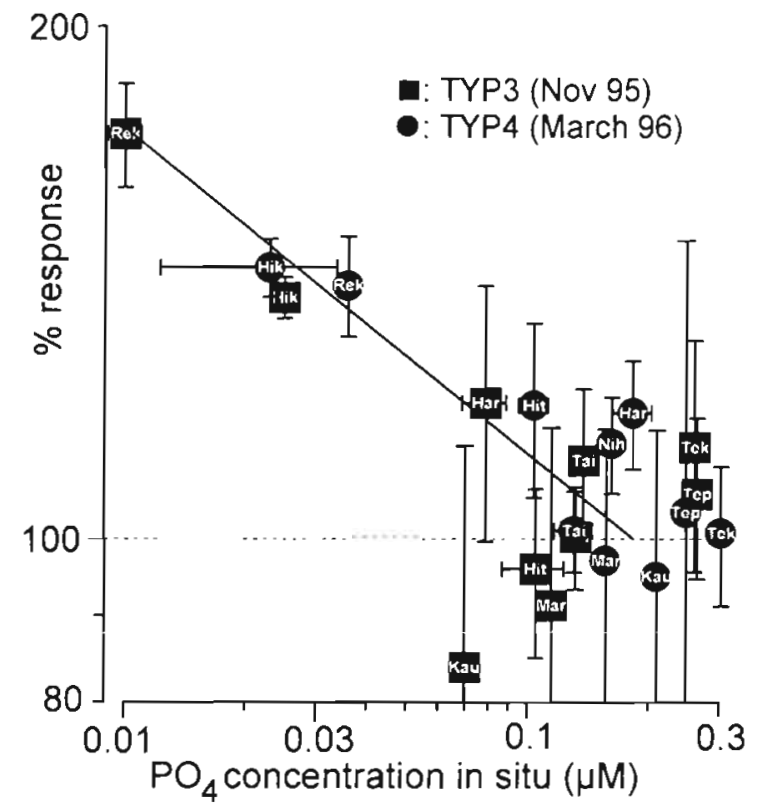

Fig. 5. Response to $\mathrm{PO}_{4}$ addition and $\mathrm{PO}_{4}$ concentration at the sites investigated. Dashed line at $100 \%$ represents control values. Atoll abbreviations as in Fig. 4 . Since $\mathrm{PO}_{4}$ was undetectable at Rek3, this point is plotted at $0.01 \mu \mathrm{M}$. Regression fit $(\log -\log$, model II) is significant even without Rek3

community turnover rate and DOC, DON, DOP or their respective ratios (Table 5).

\section{DISCUSSION}

The difficulty of assessing the nutrient status of bacterioplankton assemblages is well known since there is no single method able to demonstrate unambiguously nutrient limitation. Moreover, the term 'nutrient limitation' may refer to 2 different concepts: it may be defined from a stoichiometric point of view, as the ability of a biological compartment to produce additional biomass from increased nutrients (sensu 'Liebig'), and from a kinetic point of view, when growth rates are determined by the limiting nutrient (sensu 'Blackman') (Cullen 1991). This complication and the drawbacks identified for every experimental approach used require the use of complementary measurements to assess a possible bacterioplankton nutrient deficiency.

Our batch experiments refer to the first definition, because integrated $\mathrm{TdR}$ incorporation, a measure of bacterioplankton DNA synthesis, is an estimate of bacterioplankton production of biomass in cultures. The elimination of predators in cultures prevents protistmediated recycling of nutrients. Hence, responses of bacterioplankton growth to nutrient additions in our

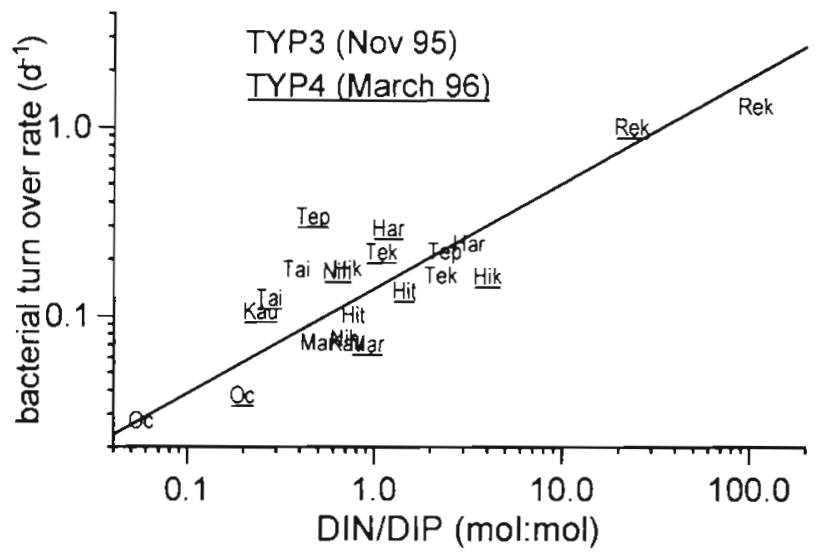

Fig. 6. Relationship between specific growth rate of bacterioplankton and dissolved inorganic nitrogen/phosphorus (DIN/DIP) ratio. Both values are averaged for the 5 stations sampled during each cruise. Solid line represents the regression fit (log-log, model II)

experimental conditions provide only an index of the potentially limiting nutrient. Results of these enrichment bioassays were completed with regressions between bacterioplankton community turnover rate and nutrients concentrations in situ. This comparative analysis refers to the second definition, i.e. the kinetic limitation of bacterioplankton growth.

Table 5. Correlation coefficients ( $\mathrm{r}$ ) and significance (p) of the regression of specific growth rate of bacterioplankton versus inorganic and organic nutrient concentrations and phytoplankton biomass and activity. Data were log-transformed. DOC, DON, DOP: dissolved organic carbon, nitrogen and phosphorus; DIN: dissolved inorganic nitrogen $\left(\mathrm{NO}_{2}+\mathrm{NO}_{3}+\right.$ $\mathrm{NH}_{4}$ ) TDN, TDP: total dissolved nitrogen and phosphorus; PP: primary production. Chl a data from Charpy \& Blanchot (1998), primary production data from J. Pagès (unpubl.). ns: not significant $(p>0.05)$

\begin{tabular}{|c|c|c|}
\hline Nutrient & I & $\mathrm{p}$ \\
\hline DOC & 0.19 & ns \\
\hline DON & 0.10 & ns \\
\hline DOP & 0.19 & ns \\
\hline $\mathrm{NO}_{2}+\mathrm{NO}_{3}$ & 0.43 & ns \\
\hline $\mathrm{NH}_{4}$ & 0.53 & 0.02 \\
\hline TIN & 0.62 & 0.003 \\
\hline $\mathrm{PO}_{4}$ & -0.49 & 0.03 \\
\hline DOC/DON & 0.08 & ns \\
\hline DOC/DOP & 0.27 & ns \\
\hline DON/DOP & 0.27 & ns \\
\hline $\mathrm{NH}_{4} / \mathrm{PO}_{4}$ & 0.63 & 0.003 \\
\hline $\mathrm{DIN} / \mathrm{PO}_{4}$ & 0.78 & 0.000 \\
\hline TDN/TDP & 0.31 & $\mathrm{~ns}$ \\
\hline Chl a & 0.62 & 0.003 \\
\hline PP & 0.56 & 0.011 \\
\hline
\end{tabular}




\section{Diversity of bacterioplankton responses to nutrient additions in Tuamotu atoll lagoons}

The 10 lagoons investigated during this study exhibited various responses to nutrient additions. These responses showed little differences between the end of the dry season (November) and the end of the rainy season (March) (Student's t-test, Table 4). The magnitude of responses differed for Hiti and Nihiru between the 2 cruises, but bacterioplankton growth appeared stimulated primarily by the same nutrients. In Tepoto Sud, the stimulation of bacterioplankton growth by ammonium during the TYP4 cruise (ambient ammonium concentration $0.01 \mu \mathrm{M}$ ) was not observed during the TYP3 cruise, where the ammonium concentration was much greater $(0.16 \mu \mathrm{M}$, Table 2$)$. In contrast, the difference in response observed for Taiaro between the 2 cruises did not correspond to consistent differences in nutrient concentrations.

Including co-stimulations, in the 10 lagoons studied during 2 different seasons, bacterioplankton growth was stimulated by $\mathrm{C}, \mathrm{N}$ and $\mathrm{P}$ additions in 4, 10 and 4 cases, respectively. For a yet unexplained reason, Marokau showed inconsistent responses among treatments during both cruises (Table 3). Bacterioplankton from 1 lagoon, Taiaro, appeared to be stimulated only following $\mathrm{C}+\mathrm{N}+\mathrm{P}$ addition. Finally, bacterioplankton from Tekokota showed insignificant responses to any addition.

While positive response to $\mathrm{N}$ amendments is the dominant characteristic within the sites tested, the variety of responses corresponds with the wide morphological diversity of these atolls.

For example, bacterioplankton from Tekokota did not show significant growth response to any nutrient addition. Tekokota is widely open to the ocean, with immersed rims representing $59 \%$ of the total perimeter (Table 1). Water exchange with the surrounding ocean is therefore likely to be very important. However, Tekokota presented bacterial numbers (Table 2), chl a and picophytoplankton numbers (Charpy \& Blanchot 1998) much lower than in oceanic waters. In contrast, inorganic nutrient concentrations appeared significantly greater in this lagoon than in surface oceanic waters and in most of the other lagoons (Table 2) during both cruises. The insensitivity of bacterioplankton growth to inorganic nutrient amendments is therefore in agreement with significant inorganic nutrient concentrations, and with the much greater bacterial community turnover rate in Tekokota $\left(0.16\right.$ to $\left.0.22 \mathrm{~d}^{-1}\right)$ than in the ocean $\left(0.028\right.$ to $\left.0.038 \mathrm{~d}^{-1}\right)$. In addition, and probably in relation with this wide opening to the ocean, this shallow lagoon is strongly colonized by ccral pinnacles (Adjeroud et al. 2000). The release from abundant corals of organic matter that benefits the bacterioplankton has been assessed repeatedly (Ferrier-
Pagès et al. 1998 and references therein). This phenomenon could provide an interpretation of why no stimulation by carbon occurred in Tekokota, unlike that observed in the ocean surface. At present, this speculation needs additional experiments. Whiledue to important differences between DON $(7.6,5.7)$ and DOP $(0.20,0.04)$ values recorded during TYP3 and TYP4 campaigns (Table 2) - it is difficult to compare DON and DOP values with the ocean, it is interesting to note that DOC is consistently lower in Tekokota than in the ocean. Bulk DOC is, however, not an accurate indicator of biodegradable DOC.

Another important exception to the general feature of predominant nitrogen stimulation of bacterioplankton growth in the sites visited is represented by RekaReka and Hikueru. In these 2 lagoons, which exhibited the lowest $\mathrm{PO}_{4}$ concentrations of all the sites visited (<0.04 $\mu \mathrm{M}$, Table 2), bacterioplankton responded positively to $\mathrm{P}$ addition. Hikueru showed enhanced bacterioplankton growth following both $\mathrm{N}$ and $\mathrm{P}$ addition, in agreement with very low concentrations for both $\mathrm{PO}_{4}$ and $\mathrm{NH}_{4}$. Only Reka-Reka demonstrated a bacterioplankton growth response following $\mathrm{P}$ addition alone. The almost closed lagoon of Reka-Reka is the shallowest and the smallest among the 10 atolls investigated (see Table 1); hence, it presents the highest ratio of soft and hard substrate areas to lagoon volume. Benthic cyanobacteria-mediated nitrogen fixation has been frequently evidenced in coral reef ecosystems (Larkum et al. 1988 and references therein), and $\mathrm{N}_{2}$-fixing filamentous benthic cyanobacteria are abundant in Tuamotu atoll lagoons (Charpy-Roubaud et al. 1997). Over the lagoons studied, Reka-Reka is likely to present the highest $\mathrm{N}_{2}$ fixation activity per unit of volume. This could explain a relative $P$ deficiency and is in agreement with the low $\mathrm{PO}_{4}$ concentration and the extremely low $\mathrm{PO}_{4} / \mathrm{DIN}$ ratio in this lagoon (Table 2)

\section{Responses to nutrient additions and ambient nutrient concentrations}

The elevated inorganic nutrient levels in the lagoon of Tekokota are in agreement with the absence of inorganic nutrient stimulation of bacterioplankton growth. At the other end of the range of $\mathrm{PO}_{4}$ concentrations, the very low levels in Hikueru and Reka-Reka are consistent with the phosphorus stimulation of bacterioplankton growth at these 2 sites. In the eastern Mediterranean, Zohary \& Robarts (1998) also showed that the differences in the magnitude of $\mathrm{P}$ effect on bacterioplankton were related to ambient $\mathrm{PO}_{4}$ concentrations. In this study, more generally, the trends of decreasing responses of bacterioplankton growth to ammonium additions (not significant since $p=0.08$ ) and increasing 
ammonium concentrations (Fig. 4) and the parallel pattern for $\mathrm{PO}_{4}$ (Fig. 5) are in agreement with the bioassay results. This correspondence suggests that the in situ concentrations reflect the nutrient status of bacterioplankton in the sites visited.

\section{Relationships between turnover rates and ambient nutrient concentrations}

In the 'Blackman' concept of nutrient limitation (Cullen 1991), the limiting nutrient determines the growth rate of the community under nutrient control. The turnover rate of bacteria was highly significantly correlated to ambient $\mathrm{NH}_{4}$ concentrations, $\mathrm{NH}_{4} / \mathrm{PO}_{4}$ ratio or DIN $/ \mathrm{PO}_{4}$ ratio (Table 5). However, a significant correlation does not prove a causal relationship. Bacterioplankton growth could react positively to enhanced phytoplankton biomass or production with increasing ammonium concentrations. Bacterioplankton community turnover rates appeared closely related to chlorophyll concentration and primary production; hence partial correlations with $\mathrm{DIN} / \mathrm{PO}_{4}$ were determined. They were still significant after stabilizing primary production $(r=0.71, p<0.001)$ or chl a $(r=0.65, p<$ $0.01)$ variances. These correlations provide another argument for a dominant $\mathrm{N}$ limitation of bacterioplankton assemblages in the Tuamotu atolls visited. On the other hand, the absence of significant correlation between bacterioplankton community turnover rate and DOC, DON, DOP or their respective ratios (Table 5) suggests that a large amount of these components may be rather refractory to bacterial consumption.

\section{Agreement with phytoplankton responses in atoll lagoons}

Using the same samples, Dufour \& Berland (1999) showed a dominant effect of $\mathrm{NO}_{3}-\mathrm{N}$ on 15 lagoon phytoplankton samples, an equivalent effect of $\mathrm{N}$ and $P$ on 4 lagoons (Reka-Reka, Hiti, Nihiru and Kauehi during TYP3) and a greater effect of $P$ in 1 case (RekaReka, TYP4). The predominance of $N$ stimulation of bacterioplankton growth is therefore in close agreement with phytoplankton limitation by $\mathrm{NO}_{3}-\mathrm{N}$ in these atoll lagoons. Similarly, $\mathrm{PO}_{4}-\mathrm{P}$ appears to stimulate both bacterioplankton and phytoplankton growth in Reka-Reka. This coincidence for stimulatory nutrients in most of the cases suggests a possible competition of bacterioplankton and phytoplankton for nutrients. Heterotrophic bacteria are considered to be efficient competitors with phytoplankton for phosphate and ammonium at low concentrations (Currie \& Kalff 1984, Wheeler \& Kirchman 1986, Caron et al. 1988, Cotner \&
Wetzel 1992). Therefore, in atoll lagoons, bacterioplankton demand for inorganic nutrients could enhance phytoplankton control by nutrient availability.

\section{Bacterioplankton response to nutrient additions in the oceanic samples}

On the other hand, the oceanic subsurface samples showed a systematic (4 out of the 4 experiments) stimulation by glucose, in one case (during TYP4 cruise) with a concomitant positive effect of $\mathrm{N}$. A comparable reaction following carbon addition was observed by Kirchman \& Rich (1997) in the Equatorial Pacific Ocean. Our limited data in southward subsurface waters in the Tuamotu area are in agreement with the regulation of bacterial growth by organic carbon.

Over the 5 oceanic sites tested for phytoplankton control during these cruises, Dufour et al. (1999) observed a dominant effect of $\mathrm{N}$ in 3 cases and similar effects of $\mathrm{N}$ and $\mathrm{P}$ in 2 cases. They considered these results to be in agreement with a DIN/PO $\mathrm{O}_{4}$ ratio below 2 . It is interesting to note that in this situation bacterioplankton growth did not appear to be primarily stimulated by $\mathrm{N}$ additions. The competitive advantage of bacterioplankton for $\mathrm{N}$ at low concentrations (Wheeler \& Kirchman 1986, Caron et al. 1988) could have reinforced phytoplankton $\mathrm{N}$ deficiency.

\section{General feature: paradox of $\mathrm{N}$ limitation in atoll lagoons}

Ammonium appears to be the nutrient that most frequently stimulates bacterioplankton growth in the lagoons tested and this has not been reported frequently in the literature. Numerous studies have investigated the regulation of bacterioplankton growth by inorganic nutrients in marine waters. Pakulski et al. (1996) recently showed an iron stimulation of bacteria in Antarctic waters. There is an increasing number of reports of phosphorus control of bacterioplankton growth in marine waters (Northwestern Mediterranean: Thingstad et al. 1998; Eastern Mediterranean: Zohary \& Robarts 1998; Gulf of Mexico: Pomeroy et al. 1995; Sargasso Sea: Cotner et al. 1997, Rivkin \& Anderson 1997). The amount of evidence for $N$ limitation of bacterioplankton growth is, however, small. Wheeler \& Kirchman (1986) showed a stimulation of bacterioplankton growth in Gulf Stream waters following additions of glucose and ammonium in combination. Carlson \& Ducklow (1996) demonstrated no stimulation of either bacterial growth rates, production or DOC consumption following $\mathrm{NH}_{4}$ or $\mathrm{PO}_{4}$ additions in the Sargasso Sea, where ambient levels of these nutri- 
ents are usually below detection limits. A limitation of bacterioplankton by organic matter was reported in the Subarctic Pacific (see Kirchman 1994) and in the Equatorial Pacific Ocean (Kirchman \& Rich 1997). To our knowledge, the only previous report of direct stimulation of bacterial activity by $\mathrm{NH}_{4}$ alone was made for the eutrophic northern Gulf of Mexico (Carman 1994).

The finding of a potential nitrogen control of bacterioplankton growth in a coral reef environment may seem paradoxical. Indeed, in these environments rich in calcium carbonate, phosphorus is generally considered as the primary limiting nutrient (Smith \& Atkinson 1984, Sorokin 1990) for several reasons. Phosphorus is known to be adsorbed strongly in the highly oxygenated top $\mathrm{cm}$ of carbonate-rich sediments, and DIN/PO ${ }_{4}$ ratios are consistently greater than Redfield ratios (Charpy-Roubaud et al. 1996 and references therein). Moreover, nitrogen fixation by cyanobacteria has been repeatedly assessed in coral reef environments (Larkum et al. 1988) including the Tuamotu Archipelago (Charpy-Roubaud et al. 1997). However, with the exception of Reka-Reka, the molar DIN/PO ${ }_{4}$ ratios are consistently low (0.2 to 4 , Table 2 ) in the water column of the atoll lagoons visited. In most of the Tuamotu atolls, lagoons represent large and relatively deep bodies of water. Benthic processes characteristic of coral reefs environments, like nitrogen fixation, seem to occur at rates too low to prevent a lack of nitrogen in the water column, contrasting with what is reported over barrier or fringing reefs. In Tikehau lagoon (average depth $25 \mathrm{~m}$ ), planktonic and benthic $\mathrm{N}_{2}$ fixation represents $13 \%$, at greatest, of the primary producers' demand for nitrogen (Charpy-Roubaud et al. 1997) and the diffusional flux of nitrogen ranges from 0.1 to $6.8 \%$ of $\mathrm{N}$ requirements of both phytoplankton and phytobenthos (Charpy-Roubaud et al. 1996). In very shallow lagoons like Reka-Reka, an increase of benthic/pelagic influence ratio may be at the origin of the low $\mathrm{PO}_{4}$ concentration in the water column and, hence, of a phosphorus control of planktonic processes.

\section{CONCLUSION}

In this study, both nutrient bioassays and correlations between the responses to nutrient additions and ambient nutrient concentrations on one side and the correlations between in situ turnover rates and DIN or $\mathrm{DIN} / \mathrm{PO}_{4}$ ratio on the other are consistent with the hypothesis of nutrient limitations of bacterioplankton growth in most of the atoll lagoons investigated.

Although nitrogen is the most frequent stimulatory nutrient for both bacterioplankton and phytoplankton (Dufour \& Berland 1999) over the sites of study, it is interesting to note that some of the deviations from this general picture were related to physical factors such as morphology, likely through their control of other biological processes. With the limited data set obtained during this study on bacterioplankton, and in another study on phytoplankton responses to nutrient additions (Dufour \& Berland 1999), we can only speculate that benthic nitrogen fixation and the diffusional flux of $\mathrm{NH}_{4}$ from soft substrates could lead to a shift from $\mathrm{N}$ limitation in the deepest open lagoons to $\mathrm{P}$ limitation in the closest and shallowest atoll lagoons. However, morphology is not the unique clue to the understanding of bacterioplankton control. Morphology alone cannot explain directly how bacterioplankton shifts from an index of strong $\mathrm{C}$ limitation in oceanic surface waters to an absence of nutrient control in the widely open Tekokota lagoon. As discussed above, the most likely explanation is the interaction between bacterioplankton and more abundant coral reef benthic communities than in the other sites (Adjeroud et al. 2000). In addition, Hiti and Tepoto Sud, the 2 lagoons showing a potential control of bacterioplankton by carbon, as observed in adjacent oceanic waters, are not characterized by the highest communication with the ocean (Table 1). It is clear that more work is needed to clarify the pattern of nutrient limitation in these coral reef ecosystems.

As already discussed by Thingstad et al. (1998), the hypothesis of an inorganic nutrient limitation on heterotrophic bacteria has important conceptual and functional consequences. Among those later studies, several have shown that carbon growth efficiency increases with decreasing substrate $\mathrm{C} / \mathrm{N}$ ratios (Kroer 1993, Jørgensen et al. 1994) and increases with increasing inorganic nutrient availability (Kroer 1993). The prevailing nutrient deficiency in the atoll lagoons documented during our study is, therefore, in agreement with the low carbon growth efficiency determined in comparable ecosystems (Tikehau and Takapoto lagoons, Tuamotu and Great Astrolabe Reef lagoon, Fiji; Torréton et al. 1997) and, in general, with the low turnover rates observed for bacterioplankton populations in these ecosystems.

A control of bacterioplankton growth by inorganic nutrients, together with the expected better affinity of bacteria rather than phytoplankton for inorganic nutrients, suggests that the nutrient limitation of primary producers observed at the same sites (Dufour \& Berland 1999) could be reinforced by bacterioplankton demand. This control hints that in most of the atolls studied, bacteria are net consumers of inorganic nitrogen and that this element is recycled by bacterioplankton grazers. At low concentrations, the advantage of bacterioplankton in the phytoplankton-bacterioplankton competition for inorganic nutrients is a consensual idea. Still, there is little evidence that this advantage 
holds in prokaryote-dominated phytoplankton assemblages typical of these oligotrophic tropical waters (Charpy \& Blanchot 1998). Coral reef lagoons provide the opportunity to study this competition in a gradient of nutrient concentrations.

Limitation of both bacterioplankton and phytoplankton by inorganic nutrients implies that these ecosystems are especially sensitive to physical perturbations such as massive release of inorganic nutrients trapped in sediments during storms, and to human perturbations such as eutrophication, a feature which should be kept in mind in the future management of economic development plans of French Polynesia.

Acknowledgements. This work was supported by the 'Institut Français de Recherches pour le Développement' (IRD), grants from the 'Programme National de Recherches sur les Récifs Coralliens (PNRCO)' and a grant from the 'Ministère de la Recherche en Polynésie Française'. We express our gratitude to the crew of the ORSTOM RV 'Alis' for their efficient help during the Typatoll cruises. We are grateful to D. L. Kirchman for helpful comments on an early draft of the manuscript and to the 5 anonymous reviewers for their useful criticisms. Thanks also to J. Pagès for the use of primary production data. This work is dedicated to our friend and colleague Sylvain Bonnet.

\section{LITERATURE CITED}

Adjeroud $M$, Andréfouët $\mathrm{S}$, Payri $\mathrm{C}$, Orempüller J (2000) Physical factors of differentiation in macrobenthic communities between atoll lagoons in the central Tuamotu Archipelago (French Polynesia). Mar Ecol Prog Ser 196 (in press)

Andréfouet S (1998) Apports de la télédétection à une approche descriptive et fonctionnelle des systèmes coralliens de Polynésie Française. PhD thesis, Université Française du Pacifique, Papeete

Carlson CA, Ducklow HW (1996) Growth of bacterioplankton and consumption of dissolved organic carbon in the Sargasso sea. Aquat Microb Ecol 10:69-85

Carman KR (1994) Stimulation of marine free-living and epibiotic bacterial activity by copepod excretions. FEMS Microbiol Ecol 14:255-261

Caron DA, Goldman JC, Dennett MR (1988) Experimental demonstration of the roles of bacteria and bacterivorous protozoa in plankton nutrient cycles. Hydrobiologia 159: $27-40$

Charpy L, Blanchot J (1998) Photosynthetic picoplankton in French Polynesian atoll lagoons: estimation of taxa contribution to biomass and production by flow cytometry. Mar Ecol Prog Ser 152:67-70

Charpy-Roubaud C, Charpy L, Sarazin G (1996) Diffusional nutrient fluxes at the sediment-water interface and organic matter mineralization in an atoll lagoon (Tikehau, Tuamotu archipelago, French Polynesia). Mar Ecol Prog Ser 132:181-190

Charpy-Roubaud C. Charpy L, Larkum AWD (1997) Contribution of $\mathrm{N}$ fixation to $\mathrm{N}$ primary productivity in the lagoon of Tikehau. In: Lessios HA (ed) Proc 8th Int Coral Reefs Symp, Panama, Vol 1. Allen Press, New York, p 803-808
Cotner JB, Wetzel RG (1992) Uptake of dissolved inorganic and organic phosphorus compounds by phytoplankton and bacterioplankton. Limnol Oceanogr 37:232-243

Cotner JB, Ammerman JW, Peele ER, Bentzen E (1997) Phosphorus-limited bacterioplankton growth in the Sargasso Sea. Aquat Microb Ecol 13:141-149

Cullen JJ (1991) Hypotheses to explain high-nutrient conditions in the open sea. Limnol Oceanogr 36:1578-1599

Currie DJ, Kalff J (1984) Can bacteria outcompete phytoplankton for phosphorus? A chemostat test. Microb Ecol 10:205-216

Delesalle B, Sournia A (1992) Residence time of water and phytoplankton biomass in coral reef Iagoons. Cont Shelf Res 12:939-949

del Giorgio P, Cole JJ (1998) Bacterial growth efficiency in natural aquatic systems. Annu Rev Ecol Syst 29:503-541

Duarte CM, Merino M. Gallegos M (1995) Evidence of iron deficiency in seagrasses growing above carbonate sediments. Limnol Oceanogr 40:1153-1158

Dufour P, Berland B (1999) Nutrient control of phytoplanktonic biomass in atoll lagoons and Pacific Ocean waters: studies with factorial enrichment bioassays. J Exp Mar Biol Ecol 234:147-166

Dufour P, Harmelin-Vivien M (1997) A research program for a typology of atoll lagoons: strategy and first results. In Lessios HA (ed) Proc 8th Int Coral reefs Symp. Panama, Vol 1. Allen Press, New York, p 843-848

Dufour P, Charpy L, Bonnet S, Garcia N (1999) Phytoplankton nutrient control in the oligotrophic South Pacific sub tropical (Tuamotu Archipelago). Mar Ecol Prog Ser 179: $285-290$

Entsch B, Sim RG, Hatcher BG (1983) Indications from photosynthetic components that iron is a limiting nutrient in primary producers on coral reefs. Mar Biol 73:17-30

Ferrier-Pagès C, Gattuso JP, Cauwet G, Jaubert J, Allemand $D$ (1998) Release of dissolved organic carbon and nitrogen by the zooxanthellate coral Galaxea fascicularis. Mar Ecol Prog Ser 172:265-274

Jørgensen NOG, Kroer N, Coffin RB (1994) Utilization of dissolved nitrogen by heterotrophic bacterioplankton: effect of substrate $\mathrm{C} / \mathrm{N}$ ratio. Appl Environ Microbiol 60: $4124-4133$

Kirchman DL (1994) The uptake of inorganic nutrients by heterotrophic bacteria. Microb Ecol 28:255-271

Kirchman DL, Rich JH (1997) Regulation of bacterial growth rates by dissolved organic carbon and temperature in the equatorial Pacific Ocean. Microb Ecol 33:11-20

Koroleff F (1970) Revised version of 'Direct determination of total nitrogen in natural waters by means of persulfate oxidation.' Int Counc Explor Sea, Paper C M 1969/C: 8. ICES, Charlottenlund

Kroer N (1993) Bacterial growth efficiency on natural dissolved organic matter. Limnol Oceanogr 38:1282-1290

Larkum AWD, Kennedy IR, Muller WJ (1988) Nitrogen fixation on a coral reef. Mar Biol 98:143-155

Murphy J, Riley JP (1962) A modified single solution method for determination of phosphate in natural waters. Anal Chim Acta 27:31-36

Pagès J, Torréton JP, Sempéré R (1997) Dissolved organic carbon in coral-reef lagoons, by high temperature catalytic oxidation and UV spectrometry. CR Acad Sci Ser IIa Geochemistry 324:915-922

Pakulski JD, Coffin RB, Kelley CA, Holder SL, Downer R, Aas P, Lyons MM, Jeffrey WH (1996) Iron stimulation of Antarctic bacteria. Nature 383:133-134

Pomeroy LR, Sheldon JE, Sheldon WM, Peters F (1995) Limits to growth and respiration of bacterioplankton in the Gulf 
of Mexico. Mar Ecol Prog Ser 117:259-268

Porter KG, Feig YS (1980) The use of DAPI for identifying and counting aquatic microflora. Limnol Oceanogr 25:943-948

Pujo Pay M, Raimbault P (1994) Improvement of the wetoxidation procedure for simultaneous determination of particulate organic nitrogen and phosphorus collected on filters. Mar Ecol Prog Ser 105:203-207

Rivkin RB, Anderson MR (1997) Inorganic nutrient limitation of organic bacterioplankton. Limnol Oceanogr 42:730-740

Sakka A, Legendre L, Gosselin M, LeBlanc B, Delesalle B, Price N (1999) Nitrate, phosphate, and iron limitation of the plankton assemblage in the lagoon of Takapoto Atoll (Tuamotu Archipelago, French Polynesia). Aquat Microb Ecol 19:149-161

Smith SV, Atkinson MJ (1984) Phosphorus limitation of net production in a confined aquatic ecosystem. Nature 307 : $626-627$

Sorokin Y (1990) Phosphorus metabolism in coral reef communities: dynamics in the water column. Aust $\mathrm{J}$ Mar Freshw Res 41:775-783

Suttle CA, Fuhrman JA, Capone DG (1990) Rapid ammonium cycling and concentration-dependent partitioning of ammonium and phosphate: implications for carbon transfer in planktonic communities. Limnol Oceanogr 35:424-433

Thingstad TF, Zweifel UL, Rassoulzadegan F (1998) P limitation of heterotrophic bacteria and phytoplankton in the

Editorial responsibility: Fereidoun Rassoulzadegan,

Villefranche-sur-Mer, France northwest Mediterranean. Limnol Oceanogr 43:88-94

Torréton JP, Dufour P (1996a) Bacterioplankton production determined by DNA synthesis, protein synthesis, and frequency of dividing cells in Tuamotu atoll lagoons and surrounding ocean. Microb Ecol 32:185-202

Torréton JP, Dufour P (1996b) Temporal and spatial stability of bacterioplankton biomass and productivity in an atoll lagoon. Aquat Microb Ecol 11:251-261

Torréton JP, Pagès J, Dufour P, Cauwet G (1997) Bacterioplankton carbon growth yield and DOC turnover in some coral reef lagoons. In: Lessios HA (ed) Proc 8th Int Coral Reefs Symp, Panama, Vol 1. Allen Press, New York, p 947-952

Wheeler PA, Kirchman DL (1986) Utilization of inorganic and organic nitrogen by bacteria in marine systems. Limnol Oceanogr 31:998-1009

Wood EPK, Armstrong FAJ, Richards FA (1967) Determination of nitrate in seawater by cadmium cooper reduction to nitrite. J Mar Biol Assoc UK 47:23-31

Yoshinaga I, Fukami K, Ishida Y (1991) Comparison of DNA and protein synthesis growth rates of bacterial assemblages between coral reef waters and pelagic waters in tropical ocean. Mar Ecol Prog Ser 76:167-174

Zohary T, Robarts RD (1998) Experimental study of microbial $P$ limitation in the eastern Mediterranean. Limnol Oceanogr 43:387-395

Submitted: March 3, 1999; Accepted: January 4, 2000 Proofs received from author(s): March 14, 2000 